\title{
The Creative Process of Creating Ringkang Haleuang Barudak Dance
}

\author{
Mas Galih Sriyanti*, Juju Masunah \\ Pascasarjana \\ Universitas Pendidikan Indonesia \\ Bandung, Indonesia \\ *nyimasgalihsriyanti@upi.edu,jmasunah@upi.edu
}

\begin{abstract}
The purpose of this paper is to describe the results of research on the creativity process of children's dance creation entitled Ringkang Haleuang Barudak. The research method is descriptive analysis. Data collection was carried out through interview techniques, observation, documentation study, and literature review. The results of data analysis were carried out by triangulation. This research found that the process of creating this children's dance was initiated by the idea of hearing stimulation and movement stimulation from the children's dance of Pagerageung, Tasikmalaya in the gending karesmén Si Ujang and DoraÉmon, which were the source from the script by Wahyu Wibisana. The source of the motion refers to the movements in the children play in Nyénang village, Cipeundeuy District, West Bandung Regency. The form is a themed dance composition in which the children dancing while singing.
\end{abstract}

Keywords-creativity process, children's game dance, social values

\section{INTRODUCTION}

The creative process is the basis of an artist making their artworks. Artworks can be created from the surrounding environment, current developments, as well as social phenomena that exist in the society. According to Murgiyanto, the creative process is the process of knowing and understanding everything that is researched or observed in the environment in order to be able to solve it endlessly [1]. The creative process of the Haleuang Ringkang dance through audio stimulation or the lyrics of the Kaulinan Barudak song.

Dance stimulation is something that can arouse thinking, enthusiasm and encourage activity. Thus stimulation is the basis or impetus and motivation for the realization of a dance work. Stimulation of dance forms is in the form of auditive and visual stimuli, namely how to hear and see [2].

The Ringkang Haleuang Barudak dance is included to the children's dance. Dance for children created by adults as a cultural statement, or creative channel, made by adults for the needs of children [3]. In this context, children are the means of professionals for adult education and experience.
With the children's songs and dance elements, we modified the steps of the synectic approach by adding training activities after introducing the concept. The next step is to explore movement using analogy and various stimulating actions, such as ideas, visuals, audio, kinesthetic, and tactile stimuli, music related to audio stimuli.

Learning music itself can be boring, so music must be combined with movement to make teaching and learning interesting. Also, music can stimulate students to explore movement. The material for dance that must be explored in the creative process is the elements of dance such as body, time, space, and energy. The result of this project is a dance for children that involves adult work [3].

Syntactically, training for adults begins with introducing concepts, practicing the material, exploring the movements, creating dances, and presenting the dance. Leading children to the community through musical drama exercises and presentations is actually a tool to teach children moral values such as creativity, empathy, caring for others, politeness, and collaboration [3]. Based on that category, the dance is considered as a child dance created by adults. Therefore, this research focuses on the creative proces in the creation of this work. Likewise, the creative process of the dance that had created has step by step in an artwork. In this case, the creative process of the Haleuang Barudak dance created by Mas Nana Munadjat Dahlan included finding ideas, composing, adjusting accompaniment, adjusting costumes and properties, and formation. The search for ideas: the basic idea originated from audio stimulation / listening to kaulinan songs and visual stimulation: the events of the children of Pagerageung, Tasikmalaya, and Kampung Nyenang, Cipeundeuy, West Bandung, who were demonstrating their kaulinan. Besides that, it was inspired by the kaulinan song script in Gending Karesmen or an opera entitled Si Ujang jeung Dora Emon by Wahyu Wibisana.

The concepts of Sundanese cultural values related to the Ringkang Haleuang Barudak Dance is tritangtu. According to Sumardjo, tritangtu is the philosophy of Sundanese society and culture, Silih Asih, Silih Asuh [4]. 
Silih asah means to educate each other, broaden each other's knowledge and inner and outer experiences. Silih asuh contains the meaning of guiding, nurturing, guarding, carefully directing to be physically and mentally healthy. Silih asih means behavior that shows sincere affection [5].

In addition, in the floor pattern, one of which is implied into parallel patterns, this can be related to the essence of Sundanese society stated by Sumardjo that harmony creativity (Siger Tengah) is how to be able to see complementary relationships, meet mutual needs, mutually exist which differ diametrically in the unity of living in harmony and peace [4].

The formulation of the problems contained in this research are: (1) How is the creative process of the Haleuang Barudak dance? (2) What is the form of the summary dance Haleuang Barudak? The purpose of writing this article is to describe the creative process and form of the summary dance Haleuang Barudak. It is hoped that this paper can be useful for cultural arts teachers to add knowledge in teaching and learning dance, for children / students it is useful for practicing dance while playing and interacting between peers, and for researcher it is useful as a research study material to increase knowledge for all parties about creativity and social values contained in the Ringkang Haleuang Barudak dance.

\section{RESEARCH METHODS}

Researcher used a qualitative paradigm with a descriptive analysis method. Qualitative research methods are often called naturalistic research methods because the research is carried out in natural conditions [6]. Sugiyono stated that the descriptive analysis method is a research method by collecting data in accordance with the actual situation, then the data is compiled, processed, and analyzed to provide an overview of the existing problems [7]. This method is used to collect information about the Ringkang Haleung Barudak dance.

The participants were Mas Nana Munadjat Dahlan, Taufik Faturohman, Iik Setiawan. The research location is in Padalarang and Pagerageung Tasikmalaya. Data collection is done by using observation, interview, and documentation techniques. Interviews were conducted with M. Nana Munajat, Taufik Faturohman, Iik Setiawan, Naning and Nina Munazah. The interview was focused on obtaining data about the creative process of the various forms of movement of the Ringkang Haleuang Barudak dance, the origins or history of the dance, and the values and meanings contained in the Ringkang Haleuang Barudak Dance. Observations were made in April 2019 and documentation studies through videos, photos, articles, writings in Galura Newspaper, Pikiran Rakyat, Galamedia. The literature review analyzes the results of previous research. Then the data is processed and compiled and analyzed to provide an overview of the dance by means of trigulation related to the text and context of the dance, describing the initial process of creating the observation-studylibrary-concept-work-concept-compilation-formation-final performance dance.

\section{RESULTS AND DISCUSSION}

\section{A. The History of Ringkang Haleuang Barudak Dance}

Ringkang Haleuang Barudak dance mainly talks about children's expressions when they are playing in the yard. Through their playing, they can feel the beauty of tolerant life, helping each other, and living together.

The traditional children's games are kaulinan and kakawihan. This traditional children's game is a reflection of Sundanese local wisdom which is in line with universal human values in general, those are: joy, mutual cooperation, respect, cooperation, love, struggle, joy, sorrow, good, bad, right, wrong, life, death and right. Those elements are something natural which is an integrated chain of events and is often found in life [8].

Starting from 2002 Mas Nana Munadjat Dahlan. believed to be the movement director in the gending karesmen entitled Si Ujang jeung Doraemon script by Wahyu Wibisana. Performed at Pagerageung from 2002 until now, 2019 in Purwakarta, 2019 at Cibuluh Tanjungsiang Subang with 1000 dancers, 2018, in Bandung, 2004 at Sasana Sabuga in front of President Megawati, 2015 at Kamuning Gading, Bogor City in the framework of HUT Sanggar Getar Pakuan Bogor City with 300 dancers. (Interview, West Bandung, April 5, 2019). The choreography consists of Mincid kendor, mincid anca, mincid gancang, Iuncat, lompat, berlari, jongkok, duduk nyanghunjar, mengayunkan kaki, mengayunkan tangan, bergandeng tangan, keupat. The Main characteristics are running, jumping, prancing, and harmony between motion and song. The author is interested in the dance, Haleuang Barudak, because this dance is simple but full of meaning.

\section{B. Creative Process}

The creative process begins with observation, literature study, making arable concepts, exploration, composing, shaping, refining, presenting through performances. The results of environmental observations and literature studies those are related to children's games in the village are then made up of arable concepts. Furthermore, movement exploration: the exploration of the creative process by looking for children's play movements, for the benefit of working on the kaulinan dance, by juxtaposing daily movements with movements that are distilled or made in the form of dance works. Compilation: The results of the exploration are arranged in terms of the sequence of movements, as well as the sequence of the dancing by combining the movements with the song, gending or music, and by combining dance with costumes and properties. The formation is made into a complete dance by first making the dance structure and its dynamic structure. Dancing and singing are related to each other that encourage creativity. This is in accordance with Juju Masunah's presentation of "children's games and songs are materials to encourage or stimulate a movement that can be arranged into dance works" [9].

This is related to the oral traditions that developed in Sundanese society. As stated by Danandjaja in Saepudin those 
there are 3 types of oral traditions [5], namely (1) oral traditions, such as folk language, traditional expressions, folk poetry, folk prose stories, and folk songs: (2) partially oral traditions, such as folk games, folk theater, folk dance, customs, ceremonies and folk parties: (3) non-oral traditions are divided into two sub-groups, there are material ones (folk architecture, folk handicrafts, folk food and drink, and traditional medicines) and non-material (traditional gestures, sound signals for folk communication, and folk music).

In the Ringkang Haleuang Barudak dance, the songs and movements of the kaulinan barudak that are danced and respected are one of the forms of oral tradition that exist in Sundanese society. The kaulinan barudak, among others, are Trang-trang kolentrang, pakaleng-kaleng agung, ucang-ucang angge, and sur-ser-sur-ser. Even though the movements in the Ringkang Haleuang Barudak dance are simple, they actually have value and meaning. As stated by Handoyo that: "Traditional games have values that look simple, but they are values that children must have in their life" [10].

\section{Movement and Meaning of the Ringkang Haleuang Barudak Dance}

The Ringkang haleuang barudak dance tends to use simple movements in the surrounding environment, the simple motion in question is in accordance with the opinion of Alan Lomax, quoted by Mulyadi, among others, saying that: "Dance is an expression taken in a life communication system that is focused on movement patterns that are often carried out in daily activities" [11].

In addition, the movements contained in the Ringkang Haleuang Barudak dance have the meaning and values of the Sundanese "Silih Asih, Silih Asah, and Silih Asuh". Silih Asah means to educate each other, broaden each other's insights and inner and outer experiences. Silih Asuh contains the meaning of guiding, nurturing, guarding, carefully directing to be physically and mentally healthy. Silih Asih means behavior that shows sincere affection [5].

The dance movement begins with a luncat to the right and left which depicts the joy of the child when it rains according to the initial lyrics, namely Praspris-praspris Paralak gebrét which is still in the Trang-trang kolentrang series. Apart from the Praspris-praspris Paralak gebrét movement, it also means the Importance of Rain Water to the Earth. Then still in the series of Trang-trang kolentrang, followed by walking while nodding, depicting movements such as the head of a porcupine, Trang-trang koléntrang, Silondok paéh nundutan, Tigebrus kana durukan, Mesat gobang kabuyutan which has the meaning of not being a useless human, don't let humans die in a state of denial or nundutan that means don't become humans in vain. Must be a human being who is motekar. Beside, from that related to the belief of the song trang-trang kolentrang in the Sundanese society, namely:

The kaulinan barudak song titled trangtrang kolentrang. In the era of the 1997s backwards, this song was considered sacred and taboo or pamali if it was sung in full from all the words it pronounced, if this song was sung during the dry season, it would not be taboo when it was sung on a rainy day. This is because the song is considered a rain-relieving mantra Thus the sacred understanding in this context is that if it is sung in the dry season, they think that it will have an impact that the dry season will be even longer. The belief in these values is still trusted and held high by local community groups in the era of the 1997s backwards, and this belief is considered beneficial for the community [12].

The next movement is Mincid (Ngareundeuk's step) which means inviting friends to continue working. Then the second: Pakaléng-kaléng agung moving hand in hand while swaying, jumping with joy which means Sauyunan or the spirit of togetherness, Pakaléng-kaléng agung's movement which means that the small people want to meet pengagung or sit parallel to pengagung or meaning togetherness is more important. The togetherness value contained in this case is the value of life without discriminating against anyone to walk side by side or hand in hand together.

The core value of togetherness is to gain kinship with a spirit of difference from various elements and groups by living side by side [13].

Third: Ucang-acang anggé Mulung muncang ka papanggé, Diudag ku anjing gedé, Anjing, gedé nu pa lebé, Ari gog-gog cungungung with dominant sitting motion swinging legs have the right to invite friends, educate oneself not to be lazy, and you have to work hard. Hard work is a term that covers an ongoing effort (never giving up) in completing the work that is its task until it's finished. Hard work does not mean working until it is complete and then stopping, what it means is leading to a big vision that must be achieved for the good / benefit of humans and their environment [14]

Hard work in this case is that life must be creative and disciplined, if we just live ucang-ucang angge or punta penta pupulung, it will be humiliated, life must be dignified, especially in the era of globalization like now, don't let be goggog ku anjing gede, means that I will lose eaten by the rigors of the times.

Fourth: sur-ser-sur-ser, a sitting dance movement with legs extended while touching the hands or means feeling the body, which means showing their feeling. Sensitivity of taste, being able to feel what other people feel, caring for others, and assessing oneself (introspection). The meaning contained in this case is how we can feel empathy to everything around us.

Empathy is a tendency to feel something that other people do if they are in the other person's situation. Because of empathy, people use their feelings effectively in other people's situations by being driven by their own emotions as if they were taking part in the movements of other people. This is where the feeling of feeling into a person or think grows to him [15]. 


\section{CONCLUSION}

The creative process of the Ringkang Haleuang Barudak Dance begins with the search for ideas, making conceptual ideas, followed by making dance compositions, costume designs and accompaniment music. The content of the dance talks about the games or kaulinan of village children. The form of the work is themed group dance. The content of the Ringkang Haleuang Barudak Dance is a kaulinan dance that has values and descriptions of applying togetherness, about feeling, tolerance, hard work, creative, adaptive, and respecting others and can easily adapt to nature, culture and the environment.

\section{ACKNOWLEDGMENT}

Praise be to Allah SWT for the blessing of my article being completed. Thanks very much to Prof. Juju Masunah as the mentor for the writing of this article, who has spent for the guide research. Thanks also to the affiliation of the Universitas Pendidikan Indonesia which organized the International Conference on Arts and Design.

\section{REFERENCES}

[1] S. Murgiyanto, Manajemen pertunjukan. Jakarta: Departemen Pendidikan dan kebudayaan Derektorat Jenderal Pendidikan Dasar dan Menengah, 1985.

[2] D. Susanti, "Penerapan Metode Penciptaan Alma Hawkins Dalam Karya Tari Gundah Kancah,” Ekspresi Seni J. Ilmu Pengetah. dan Karya Seni, vol. 17, no. 1, pp. 41-56, 2015.
[3] J. Masunah and L. Kurniawati, "Implementation of Arts Education in Society Through The Thematic Community Service Program," Harmon. J. Arts Res. Educ., vol. 18, no. 2, pp. 131-142, 2018.

[4] J. Sumardjo, Sundanese Cultural Rationality Pattern. Bandung: kelir, 2015.

[5] E. Saepudin and N.A. Damayani, "Nilai-Nilai Budaya Sunda Dalam Permainan Anak Tradisional Di Desa Sindangkerta Kecamatan Cipatujah Kabupaten Tasikmalaya," J. Ilmu Sos. dan Ilmu Polit. UIN Sunan Gunung Djati Bandung, vol. 6, no. 1, p. 198290, 2016.

[6] Sugiyono. Educational Research Methods. Bandung: Alfabeta, 2018.

[7] Sugiyono, Educational Research Methods. Bandung: Alfabeta, 2009.

[8] A. Sunaryo, J. Masunah, T. Narawati, and T. Nugraheni, "Gerak Relationship Pada Permainan Anak Sunda Sebagai Sumber Penciptaan Komposisi Tari Anak,” J. Obs. J. Pendidik. Anak Usia Dini, vol. 4, no. 2, pp. 1076-1086, 2020.

[9] J. Masunah and T. Narawati, Seni dan pendidikan seni: sebuah bunga rampai. Bandung: P4ST UPI, 2003.

[10] H. Prisia and P. Handoyo, "Permainan Tradisional Dalam Budaya Dan Perkembangan Anak," Surabaya: Univ. Negri Surabaya, 2014.

[11] S.Y. Hasnah, Seni Tari dan Tradisi Yang Berubah Studi Terhadap Penciptaan Kolektif dan Perubahan Tari Tangan Oleh Masyarakat Padang Laweh. Yogyakarta: Media Kreativa, 2013.

[12] E. Mulyati and H. Hendriyana, "Kaulinan Barudak sebagai Sumber Penciptaan Tari Anak-anak di Kabupaten Sumedang," Panggung, vol. 23, no. 3, 2013.

[13] S. Afryanto, Internalisasi Nilai Kebersamaan Melalui Pembelajaran Seni Gamelan Sunda: Sebagai Upaya Pendidikan Karakter Bagi Mahasiswa Jurusan Karawitan Di Sekolah Tinggi Seni Indonesia Bandung. Bandung: Universitas Pendidikan Indonesia, 2013.

[14] D. Kesuma, C. Triatna, and J. Permana, Character education (Study of Theory and Practice in Schools). Bandung: PT Remaja Rosdakarya, 2013.

[15] D. Goleman, "Emotional intelligence. Why it can matter more than IQ.," Learning, vol. 24, no. 6, pp. 49-50, 1996. 